Andrzej Zawadzki

Uniwersytet Jagiellonski w Krakowie

\title{
Teologia jako wyzwanie dla hermeneutyki (radykalnej)
}

\section{THEOLOGY AS A CHALLENGE TO (RADICAL) HERMENEUTICS}

The article attempts to identify certain aspects of the theological heritage that can be found in the so-called radical hermeneutics - the contemporary mainstream of the hermeneutic thoughts, which is represented among others by Gianni Vattimo and John Caput. It implies: ontologising the very concept of interpretation (there are no facts, only interpretations); move away from objectivity to the interpretation of the interpretation of productive (i.e. co-create meanings of the text by a reader) and the primacy of ethics in the act of reading (interpretation as a response to the gist of the text, and not an attempt to impose appropriation or meanings). Both the idea of interpretation productive and conviction about the role of love (caritas) in the act of interpretation can be traced as far back in the patristic thought (respectively in the writings of St. Gregory the Great and St. Augustine). Especially in the late thought by Vattimo the interpretation of Christian dogma of the Incarnation in the spirit of radical hermeneutics also plays an important role, assuming that every meaning is "embodied" in the historical, finite forms and contexts.

Key words: hermeneutics, theology, interpretation, ethics, the Incarnation.

W moim szkicu chciałbym zastanowić się krótko nad wybranymi aspektami relacji pomiędzy teologią a współczesną hermeneutyką radykalną. Charakter tych relacji określam celowo jako wyzwanie, które to słowo rozumiem w sensie dosłownym i etymologicznym, jako prowokację, czyli pro-vocare: wywoływanie, apelowanie, odwoływanie 
się do kogoś lub czegoś, mające charakter zaczepki czy nawet podrażnienia. Do czego zatem teologia prowokuje, czy też wzywa hermeneutykę radykalną? Na czym polega to wyzwanie, jaka jest jego natura? I jak hermeneutyka radykalna odpowiada na to wyzwanie i wezwanie? Hermeneutyka Prezentowane tu uwagi będą próbą zwięzłej, szkicowej odpowiedzi na te trzy pytania.

Zanim jednak do tej próby przystąpię, wyjaśnię pokrótce jak rozumiem hermeneutykę radykalną. Na bogatej mapie hermeneutycznych tradycji jest to nurt wywodzący się od Nietzschego oraz Heideggera i mający swą kontynuację głównie w filozofii Gianniego Vattima, określanej jako myśl słaba (il pensiero debole), oraz Johna Caputa, którego dwie książki - zatytułowane Radical hermeneutics (1987) oraz More radical hermenutics (2000) - użyczyły określenia całemu nurtowi radykalnej hermeneutyki. Założenia tego nurtu były już omawiane m.in. przez Norberta Leśniewskiego i Michała Januszkiewicza ${ }^{1}$, wystarczy więc tylko wskazać na kilka podstawowych kwestii, szczególnie tych najważniejszych z przyjętego przeze mnie punktu widzenia. Przede wszystkim, hermeneutyka pojęta w wersji radykalnej jest nie tylko metodyką lektury i interpretacji tekstów, lecz zostaje znacznie rozszerzona: na konteksty ontologiczne (mówiąc krótko: natura samego bytu jest interpretacyjna; nie ma faktów, są tylko interpretacje, jak głosi znane dictum Nietzschego, wielokrotnie przywoływane przez Vattima) i egzystencjalne (istotą bycia w świecie jest rozumienie i wykładnia, jak twierdzi Heidegger w paragrafach 31 i 32 Bycia $i$ czasu). W tym znaczeniu można mówić o hermeneutycznej ontologii, która w ujęciu Vattima bliska jest nihilizmowi, jeśli pojmiemy go jako „osłabienie” bycia, rozpadu wszelkich jego mocnych (esencjalistycznych) struktur, czyli utratę przez bycie charakteru „obecności” (w znaczeniu, w jakim mówi się o metafizyce obecności, czy też metafizyce obiektywistycznej. Oznacza to tyle, że nie istnieje jeden dany raz na zawsze, sztywny, zamknięty, stabilny sens świata czy tekstu jako jego „prawda”.

Następnie (i w konsekwencji przyjęcia pierwszego założenia), hermeneutyka radykalna zrywa z obiektywizmem interpretacji, czyli wykładnią jako ustalaniem uprzednio danego znaczenia tekstu (jego odtwarzaniem, reprodukcją) na rzecz interpretacji produktywnej, czyli współtworzącej, czy wręcz konstytuującej sensy i to nie tylko wykładanych tekstów, lecz ludzkiego doświadczenia w ogólności. Innymi słowy - „,sensem”, „prawdą”, „istotą” bycia są jego historyczne wykładnie. Wreszcie, kładzie ona silny nacisk na etyczne aspekty

Zob.N.Leśniewski, Ohermeneutyce radykalnej, Poznań 1998; M.Januszkiewicz, W-koło hermeneutyki literackiej, Warszawa 2007 (zwłaszcza rozdziały 6 i 8). 
interpretacji: zakwestionowanie obiektywizmu interpretacji, zasady zgodności z tekstem i zawartym w nim znaczeniem skutkuje odwołaniem się do wspólnoty interpretatorów jako ostatecznego kryterium prawomocności interpretacji. Te przytoczone skrótowo założenia radykalnej hermeneutyki nie są zresztą czymś całkowicie nowym; trzeba je raczej uznać za rozwinięcie i doprowadzenie do skrajnej postaci pewnych tkwiących już w bardziej tradycyjnym myśleniu hermeneutycznym wątków.

Te trzy wskazane wyżej aspekty: ontologizacja hermeneutyki, produktywność interpretacji i prymat etyki są radykalnymi konsekwencjami wyciągniętymi z rozpadu tzw. metafizyki obecności, czyli zjawiska, które Nietzsche nazwał nihilizmem, a Heidegger - zapomnieniem o Bycie na rzecz bytów, a które w wersji bardziej popularnej można określić, za Marquardem, jako rozstanie z filozofią pierwszych zasad, czyli odejście od idei bytu jako fundamentu, postawy, ugruntowania. Tak zarysowana tradycja filozoficzna wydaje się oczywiście bardzo odległa od myśli chrześcijańskiej, owszem- traktowana była jako jej zaprzeczenie i podważenie. Tymczasem można by sformułować tezę przeciwną, głoszącą, że punktem dojścia hermeneutyki radykalnej, czy to w wersji Vattima czy Caputa, jest właśnie problematyka teologiczna, religijna. Co więcej, to spotkanie nihilistycznej ontologii czy filozofii hermeneutycznej z chrześcijaństwem nie jest przypadkowe, przygodne czy podyktowane chwilową intelektualną modą, lecz ma charakter konieczny, stanowi logiczną konsekwencję rozwoju radykalnej hermeneutyki i jej najważniejszych założeń.

O tym spotkaniu, czy zbliżeniu świadczą już choćby tytuły późnych prac Vattima: Credere in credere (1998), Dopo la cristianità. Per un cristanesimo non religioso (2002), czy tom rozmów z Pierangelo Sequerim i Giovannim Ruggerim Interrogazioni sul cristanesimo. Cosa possiamo ancora attenderci dal Vangelo? (2000) i Caputa: Prayers and Tears of Jacques Derrida (1997), The Weakness of God: A Theology of the Event (2006), What Would Jesus Deconstruct? The Good News of Postmodernism for the Church (2007). W ten sposób radykalna hermeneutyka, wpisuje się w szerszą problematykę zwrotu religijnego we współczesnej myśli humanistycznej, zauważalnego w różnych jej tradycjach, także w fenomenologii (Marion), dekonstrukcji (późne prace Derridy), myśli krytycznej (Žižek, Badiou).

Związki hermeneutyki radykalnej z teologią - czy szerzej - z tradycją chrześcijańską są złożone i bogate, nie sposób ich wyczerpująco omówić w krótkim artykule, dlatego skupię się tylko na trzech aspektach, które wydają mi się szczególnie istotne: 1) na idei interpretacji 
produktywnej, 2) na problematyce etyki interpretacji oraz 3) na konsekwencjach, jakie ma Wcielenie dla filozofii hermeneutycznej.

Hermeneutyka

\section{Scriptura cum legentibus crescit, czyli} produktywność interpretacji

Rola wykładni tekstów świętych, zarówno na płaszczyźnie teoretycznej, filozoficznej (różne koncepcje sensu pisma i sposobów jego rozumienia, jak choćby te kojarzone ze szkołami antiocheńską i jerozolimską), jak i w praktyce (nauczanie, głoszenie słowa Bożego, jego aplikacja) są powszechnie znane i nie wymagają omówienia. Problematyka interpretacji chrześcijańskiego przekazu zyskuje jednak, w ujęciu Vattima, postać nieco odmienną i bardziej radykalną,

Mówiąc jaśniej: wydaje mi się, że - w tej mierze, w jakiej pogląd taki można uznać za zweryfikowany - fakt, że europejska kultura późnej nowoczesności „odkryła” produktywność interpretacji, czy też, co wychodzi na to samo, zrozumiała, że komentarz nie ma charakteru li tylko przygodnego, instrumentalnego, wtórnego, jest właśnie efektem interpretacji, jakiej kultura ta poddała przekaz chrześcijański. I, co za tym idzie, jest także efektem - i to bezwzględnie zbawiennym - wydarzenia chrześcijańskiego,

pisze Vattimo w szkicu Historia zbawienia, historia interpretacji ${ }^{2}$ i dodaje:

Co produkuje interpretacja produktywna? Produkuje bycie jako nowe sensy doświadczenia, nowe sposoby przejawiania się świata, które nie są po prostu inne od tych danych wcześniej, lecz dołączają się do nich w discursus, którego cała logiczność (także w znaczeniu logosu) polega na ciągłości.

Kilka rzeczy wymaga tu podkreślenia. Po pierwsze, związek interpretacji ze Zbawieniem. Jest on nie tylko, by tak rzec, okolicznościowy (trzeba słuchać Pisma i uczyć się je rozumieć, by zostać zbawionym przez zawarty w nim przekaz), ale istotowy, pomyślany dużo głębiej. Można by nawet powiedzieć, parafrazując znaną formułę Nulla salus extra Ecclesiam, że Nulla salus extra interpretationem - nie ma Zbawienia poza interpretacją, zaś interpretacji - poza historią. „Zdarzenie zbawienia (przyjście Jezusa) jest samo w sobie faktem hermeneutycznym" 3 i to na dwa sposoby: Jezus jest spełnieniem sensu Starego Testamentu, odcyfrowaniem jego przekazu i znaczenia, czyli

2 Zob. G. Vattimo, Dzieje zbawienia, dzieje interpretacji, tłum. A. Zawadzki, „Teksty Drugie” 2005, nr 4, s. 117.

Ibidem, s. 114. 
w pewnym sensie jest zamknięciem interpretacji, jej spełnieniem, czy też wypełnieniem. Ta Jego rola znajduje potwierdzenie u św. Pawła w prologu Listu do Hebrajczyków: „Wielokrotnie i na różne sposoby przemawiał niegdyś Bóg do ojców przez proroków, a w tych ostatecznych dniach przemówił do nas przez Syna" (Hbr 1,1). Jezus jest też jednak otwarciem interpretacji, gdyż, tak jak zdarzenie Zbawienia, które już zaszło, lecz musi się wypełnić, tak też Słowo Boże wymaga wykładni, która „produkuje” jego sens - w znaczeniu etymologicznym: wyciąga go, wysuwa naprzód, posuwa, ciągnie wprzód - i która rozwija się i rozwijać się może tylko w historii i poprzez nią, jest zatem ze swej istoty historyczna. W tym wątku rozważań Vatima widoczny jest wpływ radykalnej koncepcji czasowości z Bycia i czasu Heideggera, zgodnie z którą bycie jest dziejowe ze swej natury, a nie tylko ma historię jako coś wobec siebie zewnętrznego, przygodnego.

Po drugie, kwestia ciągłości i logosu jako istotnego wymiaru interpretacji. Tu patronem Vattima jest raczej Gadamer. Dzieje interpretacji, pojęte tak, jak je charakteryzuje autor Dopo la cristianità, nie są prostym, linearnym następstwem wykładni, lecz ich narastaniem zgodnie z wewnętrznym ukierunkowaniem, logosem, co broni je przed stoczeniem się w Heglowską złą nieskończoność, która, jak się zdaje, może grozić niektórym koncepcjom poststrukturalistycznym, akcentującym nieskończoną semiozę, dyseminację sensu.

Taka koncepcja interpretacji, akcentująca jej produktywność oraz rozwój zgodny z wewnętrznym logosem, jest bliska idei crescere, wzrostu, która bardzo wcześnie pojawia się w odniesieniu do interpretacji Ewangelii, a konkretnie - związku Pisma z jego czytelnikami, z podejmowanymi przez nich aktami lektury. „Pismo w jakiś sposób wzrasta wraz ze swymi czytelnikami" (Scriptura aliquo modo cum legentibus crescit) pisze Grzegorz Wielki w swym komentarzu do Księgi Ezechie$l a^{4}$; podobne sformułowanie tej myśli można odnaleźć już wcześniej, u św. Augustyna (Scriptura cum parvulis crescit) ${ }^{5}$ a, jak się zdaje, znajduje ona swe ugruntowanie w tekście Ewangelii w słynnej paraboli o siewcy, który „sieje słowo”, które wzrasta w zależności od gleby, na którą pada ( $M k$ 4, 14-20), a także w idei Królestwa Bożego jako nasienia, które kiełkuje i rośnie (Mk 4, 26-29). Sformułowania te znaczą, iż sens Pisma nie jest dany ostatecznie i od razu w wersji pełnej, „rozwiniętej”,

\footnotetext{
$4 \quad$ O wątku tym pisze P. C. Bori w książce L’interpretation infini, Paris 1991.

$5 \quad$ Zob. Augustyn, Wyznania, XII 27, 37. Na temat znaczenia tej formuły w kontekście wczesnochrześcijańskiego motywu sermo humilis (mowy skromnej) zob. E. Auerbach, Język literacki i jego odbiorcy $w$ póznym antyku łacińskim $i$ średniowieczu, tłum. R. Urbański, Kraków 2006, s. 29-64.
} 
lecz jest przekazem, przesłaniem (Heideggerowskie Geschick), który wzrasta w dziejach, które są one jego nieodłącznym wymiarem, oraz wymaga nieustannie ponawianego wysiłku interpretacji, odczytywania, w którym i dzięki któremu żyje i przejawia się.

Hermeneutyka Interpretacja - i to interpretacja produktywna - jest więc niezbywalnym, wręcz konstytutywnym elementem i wymiarem chrześcijańskiego przekazu, tak, jak jest nim też narracja, o czym pisał, m.in. Paul Ricoeur ${ }^{6}$. Ten ścisły związek chrześcijaństwa z radykalnie pojętą interpretacją może jednak ujawnić się dopiero na gruncie ontologii hermeneutycznej, która jest krytyką metafizyki obecności, metafizyki obiektywistycznej. Podobnie ma się rzecz z drugim z wymienionych wyżej wątków, czyli etyką interpretacji.

\section{Ad regnum caritatis interpretatio perducatur, czyli etyka interpretacji}

Problematyka etyczna zajmuje dziś istotne miejsce we wszystkich właściwie koncepcjach interpretacji, także w myśli Vattima, który akcentuje dobitnie ścisły związek etyki z ontologią nihilistyczną, pojęciem przekazu i interpretacją. Otóż, mówiąc najkrócej, skoro ontologia nihilistyczna opisuje proces „osłabienia” bycia w podanych wyżej znaczeniach, to etyka traci swój charakter dogmatyczny, czyli oparcie, czy też ufundowanie w jakiejś „,mocnej”, metafizycznej i uniwersalnej wizji natury, świata, społeczeństwa czy człowieka. Miejsce zasad i imperatywów zajmuje akt nieskończonej, otwartej interpretacji, która jest $\mathrm{w}$ istocie dialogiem i odpowiedzialnością jako odpowiadaniem na głosy innych, które dochodzą do nas zarówno z przeszłości, jak i np. z innych kultur. Vattimo określa te głosy jako ślady i przekazy. Nie ma tu miejsca na dokładną analizę tych pojęć, warto jednak wspomnieć, że są one dobrze ugruntowane w tradycji hermeneutycznej: według Heideggera, jako autora Zasady racji, samo bycie ma postać przekazu, w którym wyraża się jego (bycia) dziejowość; Gadamer zaś, w Prawdzie $i$ metodzie pisał o przekazie jako o sposobie bycia tradycji. Vattimo kładzie nacisk na to, że owe przekazy są samym byciem i jego „istotą”, zaś ich rozumienie i interpretacja jest, w istocie, aktem etycznym:

Te przekazy dotyczą bycia, tworzą jego sens-sens terminu bycie, terminu rzeczywistość - tak, jak są one nam dane, w naszym konkretnym

6 P. Ricoeur, L’herménutique biblique, trad. F.-X. Amherdt, Paris 2001; idem, Figuring the Sacred. Religion, Narrative and Imagination, trans. by D. Pellauer and M. I. Wallace, Minneapolis 1995; zob. też Why Narrative? Readings in Narrative Theology, S. Hauerwas, G. Jones (red.), Michigan 1989 
doświadczeniu teraźniejszości. Przekazy te - które są tematem post-metafizycznej ontologii - nie kryją w sobie żadnej istoty, żadnej głębokiej struktury bądź koniecznego prawa; przejawiają się w nich natomiast wartości historyczne, konfiguracje doświadczenia, formy symboliczne, które są śladami życia, konkretnymi postaciami bycia i których słucha się z pietas, z pobożną uwagą, na jaką zasługują właśnie jako ślady życia naszych bliźnich?

Relacje etyki i hermeneutyki mają charakter kolisty: z jednej strony bowiem etyczność interpretacji polega na uznaniu jej nieuchronnej „słabości”, czyli przygodności, historyczności, względności - tak, jak wtedy, gdy potocznie mówimy: to tylko interpretacja, tym samym odbierając naszym stwierdzeniom charakter autorytatywny i dogmatyczny. Z drugiej strony natomiast, relacja etyczna jest oparta na rozumieniu i interpretacji, na „pietystycznym” akcie nieskończonej i produktywnej wykładni przekazów jako świadectw doświadczenia. W tym właśnie miejscu jaśniejszy staje się związek Vattimowskiej etyki interpretacji z tradycją religijną.

Gdy Vattimo stwierdza, że

To nie przypadek, iż rozwijając nihilistyczne implikacje własnych założeń, hermeneutyka napotyka pojęcie miłości [carità] i odnajduje w ten sposób swój związek z religijną tradycją Zachodu'

wydaje się bliski temu, co św. Augustyn, omawiając sposoby wykładania wyrażeń przenośnych w Piśmie, pisze o interpretacji:

Oto reguła, jaką należy zachować odnośnie wyrażeń metaforycznych: należy tak długo uważnie zastanawiać się nad odczytywanym tekstem, aż interpretację sprowadzi się do jej celu, czyli do prawa miłości [donec ad regnum caritatis interpretatio perducatur] $]^{9}$.

To piękne sformułowanie św. Augustyna bezpośrednio dotyczy interpretacji wyrażeń przenośnych, ale wydaje się, że można je rozszerzyć na interpretację wszelkich miejsc niejasnych, trudnych, czyli wymagających szczególnej wrażliwości ze strony czytelnika, hermeneutycznego słuchu, wyczulenia, prawdziwej sztuki interpretacji. Uwagi autora Wyznan, utrzymane w formie postulatywnej („,należy...”) i przedstawione jako hermeneutyczna zasada, zdają się wskazywać, że nad tekstem należy się pochylić, rozważać jego przekaz uważnie

Zob. G. Vattimo, Etica dell' interpretazione, Torino 1989, s. 8.

8 Idem, Oltre l'interpretazione. Il significato dell'ermeneutica per la filosofia, Bari 1994, s. 53.

$9 \quad$ Zob.św. Augustyn, O nauce chrześcijańskiej, przeł. J. Sulowski, Warszawa 1989, s. 140. 
i z pietyzmem, z pietas, wczytywać się w ten przekaz, a nie pośpiesznie go wykładać, klasyfikować, zamykać w formułach dających złudne poczucie panowania nad sensem.

Caritas jako zasada interpretacji jest jednak nie tylko jakąś ogólną Hermeneutyka intencją, pobożnym życzeniem teorii interpretacji, ale wskazuje na cztery co najmniej konkretne i istotne momenty postawy interpretatora wobec czytanego i wykładanego przezeń tekstu. Po pierwsze, zgodnie $\mathrm{z}$ tą zasadą tekst nie jest przedmiotem, ale podmiotem, wykładamy go nie w celu zdobycia pewnej obiektywnej wiedzy, ale dlatego, że czujemy z nim istotny związek i chcemy za nim podążać - jak w formule naśladowanie Chrystusa w znaczeniu akolutheo, podążania za wzorem. Po drugie, akt interpretacji traci charakter metodyczny, nie może być oparty na jakichś obiektywnych procedurach, lecz nabiera charakteru wydarzenia, spotkania. Po trzecie, reguła caritas odbiera interpretacji charakter „egologiczny”, czy też narcystyczny, ogranicza interpretacyjną przemoc - libido interpretandi jako wyraz libido dominandi - czyli narzucanie tekstowi dowolnych wykładni (jest to chyba zagrożenie, jakie stoi przed interpretacją typu pragmatystycznego), bo odsyła do innego czyli wspólnoty, ma charakter communio. Po czwarte, i może najważniejsze, reguła caritas zmienia zupełnie sens obiegowego sformułowania wierność interpretacji. Traci ono mianowicie swój wymiar „korespondencyjny” (interpretacja wierna to interpretacja dokładna, zgodna z tekstem, tak jak mówimy o wierności literze tekstu, czyli zgodności z nim) i zyskuje wymiar etyczny, w którym na plan pierwszy wysuwa się aspekt nie przedmiotowy (wierność z czymś, w stosunku do czegoś), lecz podmiotowy - wierność komuś. Dobrze ujął ten aspekt wierności Derrida pisząc, że „wierność wiary [fidelity of the faith] znaczy więcej niż przedstawienie [representation], rządzi jego ruchem i w ten sposób poprzedza go"10.

\section{Wcielenie i interpretacja}

Wcielenie, to jak wiadomo podstawowy dogmat chrześcijaństwa, mający swe podstawy w Nowym Testamencie - zwłaszcza w Ewangelii wedtug św. Jana: „A Słowo stało się ciałem/i zamieszkało wśród nas” $(\mathrm{J} 1,14)$ - a następnie rozwijany, w różnych kierunkach i kontekstach, $\mathrm{w}$ teologii patrystycznej. Wcielenie, po grecku sarkosis, po łacinie incarnatio, u różnych pisarzy chrześcijańskich występujące też jako evanthropesis bądź ensomatosis, rozumiane jest jako zdarzenie historyczne,

10 J. Derrida, Memoirs of the blind: the self-portrait and the other ruins, trans. P.-A. Brault and M. Naas, Chicago London 1993, s. 30. 
jako podniesienie natury ludzkiej, jako ciągłe istnienie odwiecznego Logosu w ciele, wreszcie - jako misterium odkupienia i Zbawienia człowieka. Co ważne i decydujące o szczególnym charakterze Wcielenia i jego soteriologicznej misji, misterium to obejmowało także salus carnis (zbawienie ciała), dotyczyło zatem nie tylko duszy - do której ograniczała Zbawienie, w większości swych odmian, np. gnoza - lecz całego człowieka ${ }^{11}$.

Idea Wcielenia okazała się niezwykle ,produktywna” w całej kulturze zachodniej, czyli także poza ścisłym kontekstem dogmatycznym. Przynajmniej od czasów Hegla Wcielenie funkcjonowało jako ważna figura myślenia filozoficznego, czy też jako swoisty filozofem wykorzystywany w różnych kontekstach, i w tej postaci wciąż przyciąga uwagę filozofów różnych orientacji, takich jak Gadamer, Vattimo, Severino, Marion, Nancy, Henry, Didi-Hubermann - by wymienić tylko niektórych ${ }^{12}$. Rumuński filozof Constantin Noica, w swojej książce o Heglu Povestiri despre om zobaczył we Wcieleniu podstawowy fakt nowożytnej kultury europejskiej i uznał je za

sposób, w jaki zasadniczo człowiek naszej kultury dochodzi do zgody z wielkimi sensami świata, ponieważ wcielenie, tak jak i podniesienie tego, co ziemskie do istoty, miało miejsce na wszystkich planach. Cała nasza kultura jest kulturą objawienia, Syna, wcielenia. Jest faktem historycznym, że kultura europejska pod Heglu była kulturą wcielenia materii w naturę i życie, wcielenia tego co ekonomiczne w historię, a zwłaszcza wcielenia matematycznego logosu w rzeczy -jak bardzo antychrześcijańskie byłyby te momenty i jak bardzo wydawałyby się świeckie ${ }^{13}$.

Dogmat o Wcieleniu był, co najmniej od czasów Jana z Damaszku, teologiczną podstawą ikony i odegrał wielka rolę w sporach ikonoklastycznych, a poprzez to - w całej zachodniej filozofii obrazu (do nowożytności przynajmniej), co dziś pokazują liczne prace (Marion, Didi, Belting), wprowadzające na nowo Wcielenie w ponowoczesny dyskurs o obrazie.

11 Zob. Dictionnaire encyclopedique du christianisme ancienne, red. A. di Bernardino, „Les Editions du cerf” 1990, t. 1, s. 1222-1223.

12 H.-G. Gadamer, Prawda i metoda, przeł. B. Baran, Warszawa 2007, s. 564-576; G. Vattimo, Credere di credere, Milano 1996; E. Severino, L'incarnatione del Verbo, [w:] idem, Pensieri sul cristianesimo, Milano 2010; J.-L. Marion, L'idole et la distance, Paris 1977, s. 272-274;J.-L. Nancy, Verbum carofactum, [w:] idem, La Déclosion (Déconstruction du christianisme, 1), Paris 2005; G. Didi-Hubermann, L'image ouverte. Motifdel'ncarnation dansles arts visuels, Paris 2009; M. Henry, Wcielenie: filozofia ciała, przeł. M. Frankiewicz, D. Adamski, Kraków 2012. 
Wcielenie ma także istotne znaczenie dla teorii interpretacji, choć było ono stosunkowo rzadziej akcentowane, niż rola dogmatu o inkarnacji dla ukształtowania się chrześcijańskiej koncepcji obrazu. Koncepcja Wcielenia jest m.in. istotnym elementem Gadamerowskiej Hermeneutyka koncepcji języka, jak też relacji prawda - interpretacja w ujęciu Luigiego Pareysona.

Zdaniem Gadamera, to chrześcijańska idea inkarnacji, bardzo odmienna od greckiego podejścia do języka, „uchroniła myśl zachodnioeuropejską od zupełnego zapomnienia języka”, czyli od „pogrążenia w idealności sensu" ${ }^{14}$. Rozważania niemieckiego filozofa, nawiązujące głównie do myśli scholastycznej, a zwłaszcza do św. Tomasza, krążą wokół relacji myśli i jej językowego wyrazu, koncepcji słowa wewnętrznego i zewnętrznego oraz wpływu, jaki koncepcja jedności Osób Trójcy Świętej wywarła na sposoby interpretowania relacji myślenia i mówienia. $Z$ przyjętego tu punktu widzenia na podkreślenie zasługuje zwłaszcza konkluzja rozważań Gadamera, w istocie dość podobna zarówno do wspomnianych wyżej rozważań Vattima o związkach Zbawienia i interpretacji, jak i do koncepcji Pareysona. Otóż o ile Słowo Boże jest jedno oraz doskonałe i jako takie całkowicie wyraża Boską naturę, o tyle myśli, jak też słowa ludzkie są niedoskonałe i niezdolne do tego, by w pełni oddać i ogarnąć swój przedmiot co, zdaniem filozofa, powoduje przechodzenie myślenia do wciąż nowych koncepcji i ustanawia prawdziwa nieskończoność ducha. Opozycja Słowa Bożego oraz słowa ludzkiego jako opozycja jedności i wielości nie jest jednak jednoznaczna. Choć bowiem Słowo Boże jest jedno i jedyne, to jednak przejawia się wciąż od nowa w nauczaniu, a jego sensu nie można oddzielić od procesu głoszenia go ${ }^{15}$. Od takich wniosków niedaleko już do idei wzrostu Słowa w dziejach oraz interpretacji nieskończonej, czy to w ujęciu bardziej radykalnym, czyli u Vattima, czy też bardziej umiarkowanym i zapewne bliższym Gadamerowi, dla którego reprezentatywne są poglądy Luigiego Pareysona.

Według Pareysona prawda jest jedna, niewyczerpana oraz ponadhistoryczna i transcendentna wobec dziejów, ale, jednocześnie, dana jest tylko poprzez „historyczne otwarcia” (aperture storiche), czyli konkretne formy kulturowe, w których się zawiera, ale do których się nie ogranicza. Prawda jest więc zawsze „wcielona”, przybiera konkretne, skończone i zróżnicowane postaci historyczne i kulturowe, gdyż inaczej byłaby w ogóle niedostępna myśli i poznaniu, albo też dostępna jedynie na drodze negatywnej, apofatycznej, która zdaniem włoskiego

14 Zob. H.-G. Gadamer, Prawda i metoda, op. cit., s. 564, 565.

15 Ibidem, s. 574-576. 
filozofa niebezpiecznie zbliża się do nihilizmu. Z drugiej strony, prawda nie ogranicza się do swych wymiarów historycznych i kulturowych, gdyż, gdyby tak było, groziłaby jej obiektywizacja, czyli zamknięcie w zastygłych, jednoznacznych i ograniczonych postaciach, jakimi są np. ideologie; to niebezpieczeństwo obiektywizacji Pareyson określa jako idolatrię, rozumiejąc przez ten termin wzięcie jakieś interpretacji prawdy-za prawdę samą, czyli zawłaszczenie jej i sprowadzenie wyłącznie do ludzkich poznawczych schematów:

to co 'ponadkulturowe' ['metaculturale'] to właśnie to, co wciela się w różne formy kulturowe i historyczne, nie utożsamiając się z nimi jednak, lecz podpierając je i ożywiając, nadając im znaczenie i wytwarzając dzięki własnej nieskończonej wirtualności, dzięki czemu znajduje w nich nie tylko jedyną swą siedzibę, lecz także jedyny sposób przejawiania się, wręcz jedyny modus vivendi, ponieważ nie ma innego życia niż te właśnie formy, w które od czasu do czasu się wciela i w których znajduje swe miejsce ${ }^{16}$.

Rola interpretacji w ujęciu Pareysona polega właśnie na tym, iż broni ona prawdy przed tymi dwoma przeciwnymi niebezpieczeństwami: apofatyzmem, czyli niedostępnością i niewyrażalnością oraz idolatrią, czyli obiektywizacją i zawłaszczeniem. Dzięki interpretacji bowiem prawda staje się myśleniu dostępna, ale zawsze jedynie jako niewyczerpana, niemożliwa do ostatecznego uchwycenia.

Także interpretacja produktywna oraz interpretacja etyczna w przedstawionych wyżej „radykalnych” wersjach - wyrastają z idei Wcielenia, co pokazuje dobrze dokonana przez Vattima interpretacja Inkarnacji jako „osłabienia” sacrum. To właśnie w tej interesującej i oryginalnej, choć z pewnością kontrowersyjnej interpretacji wyraża się najpełniej wspomniane na początku tego szkicu spotkanie nihilistycznej ontologii hermeneutycznej i tradycji chrześcijańskiej.

Według autora Credere di credere filozofa Wcielenie, kenosis, uniżenie to utrata przez sacrum „mocnego”, „przemocowego” charakteru, proces paralelny w istocie do „osłabienia Bycia”, zapomnienia o nim - czyli zjawiska, na którym jest oparta ontologia nihilistyczna i hermeneutyczna. Wcielenie jako osłabienie znaczy wejście Boga w ciało, historię, ludzką kondycję, z czego wynika, po pierwsze, utrata naturalistycznego, naznaczonego przemocą i ufundowanego w naturze charakteru sacrum (opisanego najpełniej w pracach René Girarda), zaś po drugie - osłabienie radykalnej transcendencji sacrum (czyli tej jego cechy, która jest akcentowana najmocniej przez Lévinasa i Derridę). 
Cywilizacyjnym wyrazem tak pojętego Wcielenia jest sekularyzacja, która ma pozytywne znaczenie dla religii. Przede wszystkim dlatego, że uznanie sekularyzacji nie za odejście od religijnych korzeni, lecz za logiczną konsekwencję najgłębszych zasad chrześcijaństwa Hermeneutyka usuwa konflikt religii i ateistycznej nowoczesności, owszem, pozwala uznać tę pierwszą za najważniejsze zdarzenie w obrębie tej drugiej. Następnie, sekularyzacja jako przejaw Wcielenia-osłabienia ma wymiar pozytywny gdyż może zostać uznana za oczyszczenie przekazu chrześcijańskiego z residuum metafizycznego, z pozostałości „sacrum naturalnego”, czyli „mocnej” wersji religii, którą, w ujęciu Vattima zastępują właśnie interpretacja oraz caritas - obie przeciwstawiona dążeniu do obiektywizacji, wyczerpania i zawłaszczenia prawdy chrześcijańskiego przekazu ${ }^{17}$.

Na postawione na początku pytanie o to, do czego wzywa radykalną hermeneutykę teologia, można tak odpowiedzieć: wzywa ją do jej własnej istoty, czyli do rozpoznania siebie w tradycji chrześcijańskiej, do uznania teologicznych korzeni własnych postulatów, pozornie odległych od dziedzictwa religijnego czy wręcz otwarcie mu przeczących.

Słowa kluczowe: hermeneutyka, teologia, interpretacja, etyka, Wcielenie.

\section{Bibliografia:}

1. Auerbach E., Język literacki i jego odbiorcy $w$ późnym antyku tacińskim i średniowieczu, tłum. R. Urbański, Kraków 2006.

2. Augustyn, O nauce chrześcijańskiej, przeł. J. Sulowski, Warszawa 1989.

3. Augustyn, Wyznania.

4. Bori P. C., Linterpretation infini, Paris 1991.

5. Derrida J., Memoirs of the blind: the self-portrait and the other ruins, trans. P.-A. Brault and M. Naas, Chicago London 1993.

17 Dokonana przez Vattima interpretacja sekularyzacji jako konsekwencji Wcielenia, a wręcz „istoty” chrześcijaństwa może brzmieć osobliwie, nawet paradoksalnie, ale włoski filozof nie jest odosobniony w tych poglądach: Maurice Gauchet (Le désenchantement du monde. Une historie politique de la religion, Paris 1985, s. I-II) widzi w sekularyzacji i modernizacji społeczeństw zachodnich część dziedzictwa religijnego, a chrześcijaństwo nazywa „religią wyjścia religii" (la religion de la sortie de religion). Katolicki filozof włoski Emanuele Severino (w szkicu Esiste la fede? zawartym w książce Pensieri sull cristianesimo, Milano 2010 s. 87) pisze natomiast, ,że sekularyzacja i profanacja wiary należą do istoty czystej wiary”, bo wiara nie jest wiedzą pewną, metafizyczną, opartą na idei pewności (certum), lecz jest czymś poniżej wiedzy, czyli, konsekwentnie, naznaczona jest wątpieniem. 
6. Dictionnaire encyclopedique du christianisme ancienne, (red.) A. di Bernardino, Les Editions du cerf 1990, Vol. 1.

7. Didi-Hubermann G., Limage ouverte. Motif de l'ncarnation dans les arts visuels, Paris 2009.

8. Gadamer H.-G., Prawda i metoda, przeł. B. Baran, Warszawa 2007.

9. Gauchet M., Le désenchantement du monde. Une historie politique de la religion, Paris 1985.

10. Henry M., Wcielenie: filozofia ciała, przeł. M. Frankiewicz, D. Adamski, Kraków 2012.

11. Januszkiewicz M., W-koto hermeneutyki literackiej, Warszawa 2007.

12. Leśniewski N., O hermeneutyce radykalnej, Poznań 1998;.

13. Marion J.-L., L'idole et la distance, Paris 1977.

14. Nancy J.-L., Verbum caro factum, [w:] Nancy J.-L., La Déclosion (Déconstruction du christianisme, 1), Paris 2005.

15. Noica C., Povestiri despre om (după o carte lui Hegel), Bucuresti 1980.

16. Pareyson L., Verità e interpretazione, Milano, 1971.

17. Ricoeur P., Figuring the Sacred. Religion, Narrative and Imagination, trans. by D. Pellauer and M. I. Wallace, Minneapolis 1995.

18. Ricoeur P., L'herménutique biblique, trad. F.-X. Amherdt, Paris 2001.

19. Ricoeur P., Why Narrative? Readings in Narrative Theology, S. Hauerwas, G. Jones (red.), Michigan 1989.

20. Severino E., Esiste la fede, [w:] Severino E., Pensieri sull cristianesimo, Milano 2010.

21. Severino E., L'incarnatione del Verbo, [w:] Severino E., Pensieri sul cristianesimo, Milano 2010.

22. Vattimo G., Credere di credere, Milano 1996.

23. Vattimo G., Dzieje zbawienia, dzieje interpretacji, tłum. A. Zawadzki, „Teksty Drugie” 2005, nr 4.

24. Vattimo G., Etica dell' interpretazione, Torino 1989.

25. Vattimo G., Oltre l'interpretazione. Il significato dell'ermeenutica per la filosofia, Bari 1994. 